\title{
Factors of sustainable development of electronic commerce in Russian retail
}

\author{
Oksana Pirogova ${ }^{1, *}$ and Boris Pivovar ${ }^{2}$ \\ ${ }^{1}$ Peter the Great St. Petersburg Polytechnic University, 195251, 29 Polytechnicheskaya str., St. \\ Petersburg, Russia \\ ${ }^{2}$ The Russian Presidential Academy of National Economy and Public Administration, 119571, \\ Prospect Vernadskogo, 84, bldg 2, Moscow, Russia
}

\begin{abstract}
Digitalization affects many industries, including the service sector. In this area, under the influence of the "digitalization" of the economy, there is a tendency to transfer consumer demand to the Internet. The processes of digitalization of retail trade began several years ago, but during the coronavirus pandemic, they accelerated several times, as evidenced by the growth of turnover of Internet companies. The aim of the study is to predict the share of e-commerce in the structure of retail trade. Research methods: description, comparison, analogy, generalization and analysis. In the course of the study, the dynamics of retail trade, including Internet trade, was analysed, the impact of the pandemic on retail trade was analysed, and factors affecting structural changes in retail trade were identified. On the basis of linear regression, a model of the influence of the growth rate of e-commerce volumes on the growth rate of offline turnover is constructed. The forecast showed an increase in e-trade turnover, therefore, an increase in its share in the overall structure of retail trade. The pandemic accelerated the increase in the share of Internet trade in 2020 and adjusted forecasts for the following periods. The significant growth of ecommerce caused by the pandemic will slow down in the coming years, but the trend of buyer and seller switching to the Internet will continue, which will lead to structural changes in retail.
\end{abstract}

\section{Introduction}

In the past few years, many companies have appreciated the benefits of e-commerce and decided to move their delivery channels for their goods and services to the Internet. In this regard, there is a need for high-quality storage facilities. Despite the restrictive measures associated with the coronavirus pandemic, the warehouse segment suffered the least due to the increase in demand for warehouse space from retailers and e-commerce participants. The popularization of e-commerce (internet trade) in the past few years has led to an increase in demand for warehouse space from its participants. Often, an online retailer does not specialize in one type of product sold, and its assortment, in comparison with a classic retailer, can be much wider. Therefore, it requires special characteristics of an existing or

\footnotetext{
* Corresponding author: kafedra17@,rambler.ru
} 
planned warehouse. The increasing complexity of the characteristics of a warehouse leads to an increase in the cost of its construction and maintenance; therefore, rental rates for such areas are higher than the market average [1]. Over the past few years, there has been an upward trend in the average rental rate for warehouse real estate.

Throughout the studied period, there has been a decrease in the vacancy rate for warehouse space, with the exception of the first half of 2020 (Figure 1). Despite a significant increase in the commissioning of new space in Russia, the vacancy rate is decreasing, which indicates a high demand for this type of space [2].

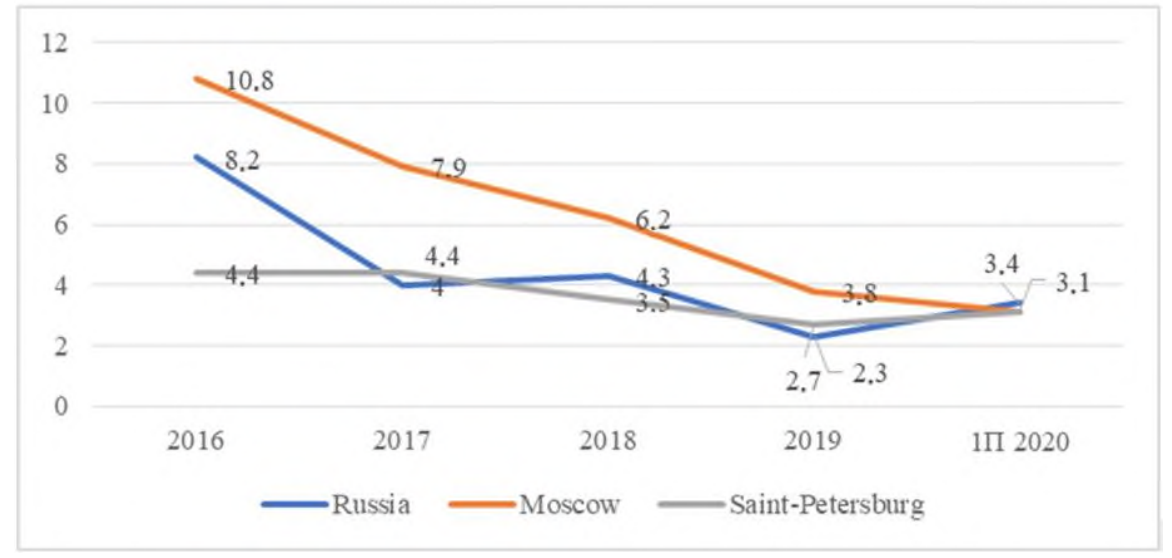

Fig. 1. Dynamics of the vacancy rate of warehouse premises in \%, 2016-2020.

The aim of the study is to predict changes in the dynamics of e-commerce in the structure of retail trade.

\section{Materials and methods}

The main trend in retail is considered to be the expansion of the presence of online retailers. Both new players and well-established companies that initially operated in the offline space go online. Online trading has a number of advantages and differences over traditional trading. Table 1 provides a comparative analysis of online and offline trading.

Comparative analysis showed that online trading has a number of advantages over offline trading, but it is still inferior in terms of a number of factors. Given the intractable drawbacks of online trading, we can conclude that traditional retailers will remain in the market over the next decade, but the share of online trading will still increase as the quality of service improves [3].

The growth driver of the presence of online retailers can be called restrictive measures associated with the coronavirus pandemic in 2020. The Covid-19 pandemic primarily affected the trade and services sector, where the fall occurred in almost all indicators. At the same time, companies engaged in retail trade turned out to be more prepared for the difficulties that arose: many by this time already had multichannel sales (through a point of sale, Internet platforms). Other companies in the service sector, requiring the personal presence of the client for the implementation of the service, almost or completely suspended their activities [4].

This study used analytical methods such as description, data grouping, cause-effect analysis, correlation-regression analysis. The use of these methods allowed the authors to connect individual facts about the current state of the retail structure, thereby identifying the relevant realities, problems and trends in the development of this sector of the economy $[5]$. 
Table 1. Comparative analysis of sales channels.

\begin{tabular}{|c|c|c|}
\hline Criterion & Offline trading & Online trading \\
\hline Merchandising & $\begin{array}{l}\text { Attraction of labor for the } \\
\text { layout of goods in the sales } \\
\text { area in accordance with the } \\
\text { standards; analysis of client } \\
\text { flows }\end{array}$ & $\begin{array}{l}\text { Use of various services of product } \\
\text { recommendations; analysis of customer } \\
\text { behavior in the network; personalized } \\
\text { search; responsive content, mailing lists }\end{array}$ \\
\hline Communications & $\begin{array}{l}\text { Personal communication } \\
\text { with the client; larger } \\
\text { retailers use communication } \\
\text { via SMS, email marketing } \\
\text { letters }\end{array}$ & $\begin{array}{l}\text { Lack of personal communications; use } \\
\text { of chat bots, communication in } \\
\text { messengers; SMS notifications and calls }\end{array}$ \\
\hline $\begin{array}{l}\text { Product } \\
\text { categories }\end{array}$ & $\begin{array}{l}\text { A wide range of products, } \\
\text { including products for which } \\
\text { sale is possible only with a } \\
\text { license }\end{array}$ & $\begin{array}{l}\text { Mainly long-term storage goods; } \\
\text { distance selling of alcohol, cigarettes, } \\
\text { certain medicines, etc. is prohibited by } \\
\text { law (exception: pre-order and self- } \\
\text { delivery of the order) }\end{array}$ \\
\hline $\begin{array}{l}\text { Online } \\
\text { checkouts and } \\
\text { payment } \\
\text { methods }\end{array}$ & $\begin{array}{l}\text { Using online checkouts; the } \\
\text { possibility of cash } \\
\text { settlement, payment using a } \\
\text { bank card }\end{array}$ & $\begin{array}{l}\text { Using online checkouts; cash payment } \\
\text { upon receipt of the order, payment by } \\
\text { credit card, payment using payment } \\
\text { systems }\end{array}$ \\
\hline $\begin{array}{l}\text { Warehouse } \\
\text { management }\end{array}$ & $\begin{array}{l}\text { Large networks require a } \\
\text { wide supply chain: federal, } \\
\text { regional, city distribution } \\
\text { warehouse }\end{array}$ & $\begin{array}{l}\text { For small online stores it is possible to } \\
\text { work according to the "dropshipping" } \\
\text { scheme - direct delivery of goods from } \\
\text { the supplier to the buyer, in which the } \\
\text { seller does not store the goods in his } \\
\text { warehouse, the goods are sent to the } \\
\text { customer from the manufacturer's } \\
\text { warehouse }\end{array}$ \\
\hline $\begin{array}{l}\text { Analysis of } \\
\text { consumer } \\
\text { activity }\end{array}$ & $\begin{array}{l}\text { Analysis of the shopping } \\
\text { cart using loyalty cards, } \\
\text { analysis of consumer flows } \\
\text { in the store }\end{array}$ & $\begin{array}{l}\text { The ability to analyze financial } \\
\text { indicators, sales data, advertising } \\
\text { performance and other parameters }\end{array}$ \\
\hline Localization & $\begin{array}{l}\text { A retail facility should be } \\
\text { located in places where high } \\
\text { customer flows are } \\
\text { concentrated in order for the } \\
\text { investment to pay off }\end{array}$ & $\begin{array}{l}\text { Products from online stores can be } \\
\text { delivered to almost anywhere in the } \\
\text { world, the effectiveness of such a } \\
\text { business rather depends on advertising } \\
\text { and the uniqueness of the product. }\end{array}$ \\
\hline $\begin{array}{l}\text { Waiting time for } \\
\text { goods }\end{array}$ & $\begin{array}{l}\text { Possibility to receive goods } \\
\text { here and now, if available in } \\
\text { the store }\end{array}$ & $\begin{array}{l}\text { Delivery of goods from online stores } \\
\text { most often takes from } 1 \text { day to several } \\
\text { months }\end{array}$ \\
\hline
\end{tabular}

The dynamics of the index has been unstable throughout the year. At the end of the first quarter, before the start of the restrictions, there was a significant increase in retail sales in rubles. This is due to the unprecedented uncertainty in consumer sentiment in the coming months. Many made purchases, fearing a shortage of goods and higher prices.

\section{Results and discussion}

During the second quarter, there was a decrease in consumer demand due to the introduction of a general quarantine (Figure 2). Recovery was outlined only towards the end of the second quarter $[6,7,8]$.

As stated earlier, the retail business has proven to be more prepared for the pandemic as it has developed multi-channel over the past few years. While few are abandoning physical customer touchpoints, demand is still shifting to the Internet.

Online commerce in recent years has become a new driver of growth, and the introduced quarantine restrictions have significantly accelerated the growth rates of online 
sales both in the world and in Russia. The growth of online commerce is accompanied by restrictions on cross-border travel, which also affects the increase in the volume of e-trade. Figure 3 shows the dynamics of the volume of the e-commerce market in Russia from 2016 to 2020 .

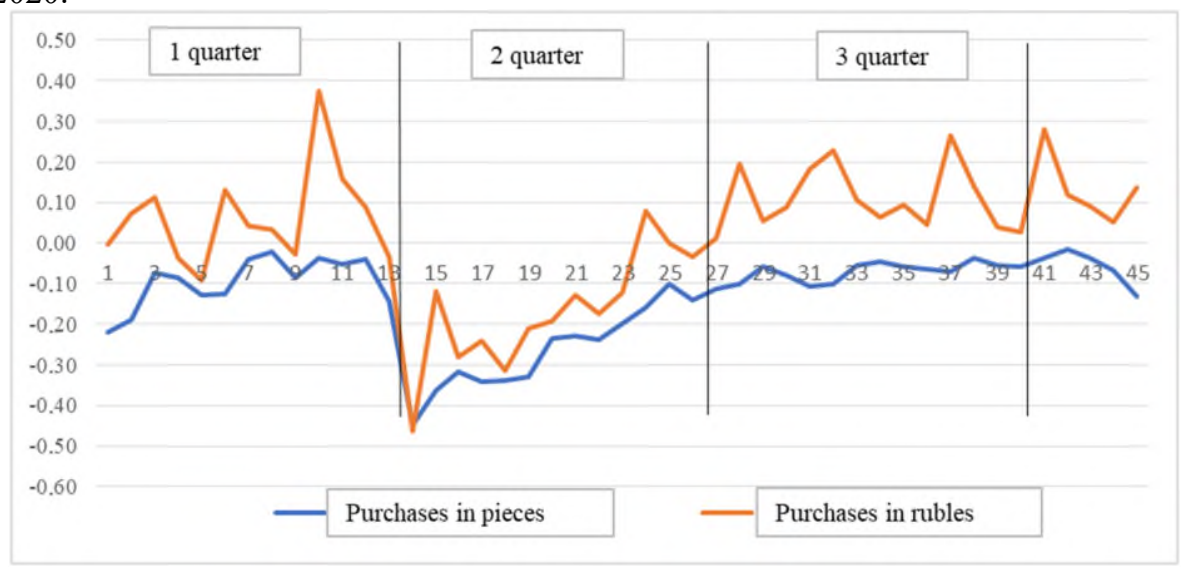

Fig. 2. Index of retail business activity, 2020 [1].

Figure 3 shows that the share of e-commerce turnover in the total turnover began to grow in 2018 (from 4 to 5\% in 2019) and, according to forecasts, from 5\% in 2019 to $10 \%$ by the results of 2020 . The twofold increase in the share of e-turnover was influenced by several factors $[7,9,10,11,12]$ :

- the rise in popularity of online shopping in recent years;

- the closure of many shopping centers in Russian cities due to the pandemic, a significant increase in online purchases;

- the appearance in recent years of delivery services in many supermarkets;

- the emergence of "dark-stores" and "dark-kitchen" (stores and services that do not have a physical place to interact with the customer (delivery services for products "Samokat", "Yandex-Shop", delivery of ready-made meals "Ready Kitchen SPb", "GrowFood" etc.).

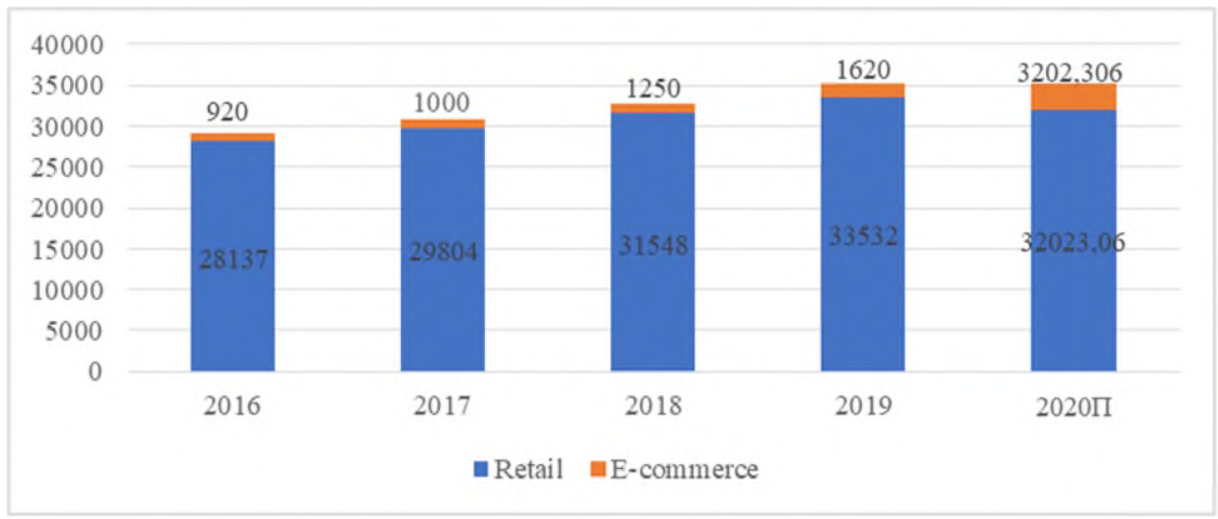

Fig. 3. The structure of trade in Russia, billion rubles [2].

According to the forecast of the consulting agency in the field of e-commerce and digital markets "Data Insight", the average growth of e-commodity turnover from 2020 to 2024 will be $33.2 \%$ per year and by the end of the forecast period will reach 7,200 billion rubles. Growth rates will gradually decline: $44 \%$ at the end of 2020 to $27 \%$ at the end of 
2024. Along with the growth of e-turnover, the share of e-commerce in the total structure of retail turnover will grow (19\% in 2024 against $10 \%$ at the end of 2020). Figures 4-6 show the predicted dynamics of the digital market in Russia [13].

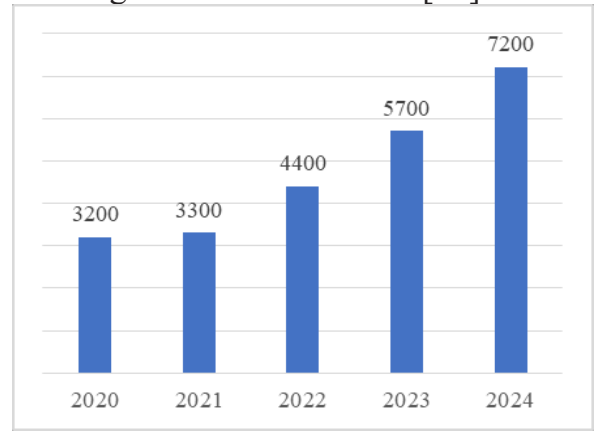

Fig. 4. Volumes of e-trade in Russia, billion rubles.

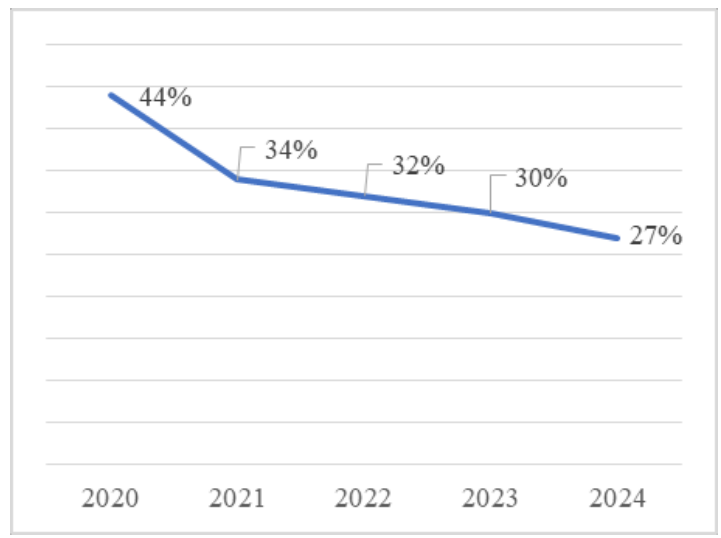

Fig. 5. Growth rates of e-turnover, \%.

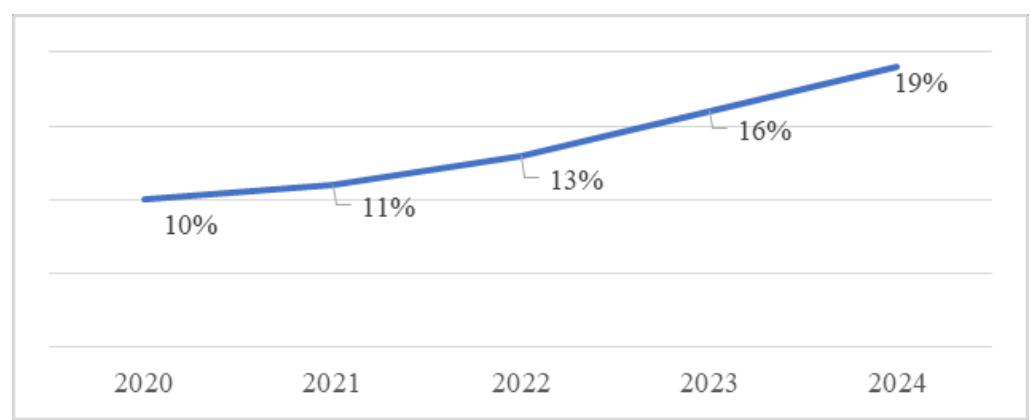

Fig. 6. The share of e-turnover in the overall structure of turnover, $\%$.

Since 2019, the growth rate of the market has accelerated relative to previous years due to large-scale advertising events of Internet giants, and the arrival of new customers who have not made online purchases before [9]. The 2020 pandemic has only accelerated this pace and, according to the results of the five-year period, according to the Data Insight forecast, will bring about 1.6 trillion rubles in addition. The natural growth of e-commerce without taking into account the impact of the corona crisis (but taking into account investments in Internet trade by the largest players) would have amounted to $26.6 \%$ over the same period, that is, the market in 2024 would have amounted to 5.6 trillion rubles. 
Thus, the crisis factors additionally bring 1.6 trillion rubles to online sales over five years $[13,14]$.

The frequency of shopping is predicted to increase even after the end of the pandemic, consumers in many cases will prefer online shopping instead of going to crowded shops and malls, this factor will matter in 20 and 21 years.

Most of all, according to experts, among retail formats, hypermarkets will suffer, which in recent years have been losing their customer flow. Customers in traditional retail are increasingly switching from large purchases of goods for one to two weeks in a large hypermarket to purchases several times a week, but in a supermarket "near the house". At the same time, long-term storage goods - the main product of hypermarkets - began to be bought more often using delivery services to save time and effort. However, perishable goods (vegetables, fruits, meat products) are purchased at smaller retail outlets, which will be popular for a long time, given the particulars of delivery of goods.

In 2019, a trend emerged for the fast delivery of groceries and ready-to-eat meals. According to research by the agency Havas Russia and Mail.ru Group, the target audience of this segment is young people. For example, Perekrestok (X5 Retail Group) launched Perekrestok.Bystro and Perekrestok.Vprok services, which allow you to receive readymade food and groceries within an hour. VkusVill also launched food delivery from 29 minutes in partnership with Gett Delivery, a food delivery service in 15 minutes, Samokat, Yandex.Lavka. In the segment "Household appliances" there was a service of fast delivery of goods from "M.Video" [9, 10, 11].

Table 2. Input data for analysis.

\begin{tabular}{|c|c|c|c|c|c|c|}
\hline Period & $\begin{array}{c}\text { Retail } \\
\text { turnover, } \\
\text { RUB } \\
\text { billion } \\
{[\mathbf{1 0 ]}}\end{array}$ & $\begin{array}{c}\text { Share of } \\
\text { e- } \\
\text { turnover, } \\
\mathbf{\%}\end{array}$ & $\begin{array}{c}\text { Offline } \\
\text { trade } \\
\text { volume, } \\
\text { RUB } \\
\text { billion, } \\
{[\mathbf{2}]}\end{array}$ & $\begin{array}{c}\text { Volume of } \\
\text { e- } \\
\text { turnover, } \\
\text { RUB } \\
\text { billion }\end{array}$ & $\begin{array}{c}\text { Offline } \\
\text { trade } \\
\text { turnover } \\
\text { change, } \% \\
\text { over half a } \\
\text { year } \\
(\boldsymbol{y})\end{array}$ & $\begin{array}{c}\text { E- } \\
\text { turnover } \\
\text { change, } \\
\text { over half } \\
\text { a year } \\
(\boldsymbol{x})\end{array}$ \\
\hline 2016 & 28300 & $3 \%$ & 27451 & 849 & $-6 \%$ & $+58.4 \%$ \\
\hline 2017 & 30749 & $3 \%$ & 29826 & 922 & $+8.7 \%$ & $+8.65 \%$ \\
\hline 2018 & 31548 & $5 \%$ & 30248 & 1300 & $+1.4 \%$ & $+40.9 \%$ \\
\hline 2019 & 33532 & $6 \%$ & 31832 & 1700 & $+5.2 \%$ & $+30.8 \%$ \\
\hline 2020 & 31788 & $9 \%$ & 29288 & 2500 & $-8.0 \%$ & $+47.1 \%$ \\
\hline $\begin{array}{c}2021 \\
\text { forecast }\end{array}$ & 22060 & $11 \%$ & 29760 & 3300 & $+1.6 \%$ & $+32.0 \%$ \\
\hline $\begin{array}{c}2022 \\
\text { forecast }\end{array}$ & 34118 & $13 \%$ & 29718 & 4400 & $-0.1 \%$ & $+33.3 \%$ \\
\hline $\begin{array}{c}2023 \\
\text { forecast }\end{array}$ & 35073 & $16 \%$ & 29373 & 5700 & $-1.2 \%$ & $+29.55 \%$ \\
\hline $\begin{array}{c}2024 \\
\text { forecast }\end{array}$ & 35950 & $19 \%$ & 28750 & 7200 & $-2.1 \%$ & $+26.3 \%$ \\
\hline
\end{tabular}

The removal of bans on distance selling of medicines, alcohol and other goods that are currently on the "stop list" can increase the turnover of Internet commerce.

From the above facts, it follows that an active growth in the share of e-commerce in Russia, an increase in the frequency of online purchases will lead to a decrease in the growth rate of turnover of offline operators, and a change in trade formats. With the help of correlation-regression analysis, we will reveal how strongly the volume of Internet trade growth influences the change in retail trade in offline format.

The analysis was carried out in MS Office Excel using data on the volume of turnover of offline companies and the volume of turnover of Internet commerce for 2016-2024, and for $2 \mathrm{H}$ 2020-2024, forecast values were taken. 
Correlation analysis was carried out to determine the relationship between the indicators of the volume of offline retail trade and the volume of e-commerce. In addition, a regression analysis was carried out using the data in Table $2[15,16]$.

To build the model, the equation of the resulting indicator was used:

$$
y=b 0+b 1 \cdot x,
$$

where, $\mathrm{y}$ - resulting indicator (Growth rate of offline turnover, \%); b0, b1 - regression coefficients; $\mathrm{x}$ - factor that determines the resulting indicator (growth rate of the volume of e-turnover, \%). The results of the regression analysis performed graphically are shown in Figure 7.

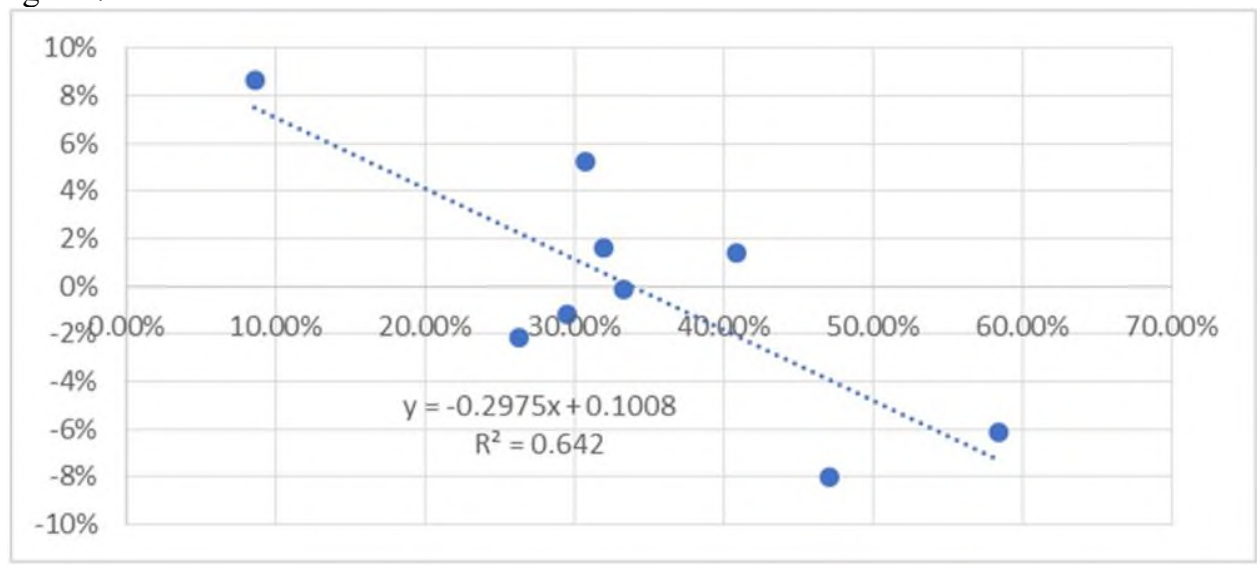

Fig. 7. Regression model of the influence of the growth rate of e-commerce volumes on the growth rate of offline goods turnover, 2016-24.

The regression analysis performed graphically showed that the models of the influence of factors (growth rates of e-commerce volume) on the resulting indicator (growth rates of offline goods turnover) make sense.

The equation of the resulting indicator, built on retrospective and forecast indicators, is as follows:

$$
y=-0.2975 x+0.1008,
$$

where $\mathrm{R} 2=0.642 . \mathrm{R} 2-$ an indicator characterizing the reliability of the constructed regression model, which tends from 0 to 1 , the closer to 1 , the higher the reliability of the model - the influence of the factor on the resulting indicator is higher. R2 for the constructed model, it turned out to be 0.642 , which indicates a normal level of dependence of the indicators of the growth rate of offline goods turnover and the growth rate of the volume of e-goods turnover.

The regression model is considered unreliable if the R2 score is $<0.6$. In this case, R2 turned out to be higher, but it corresponds to the borderline values, which may indicate a lack of historical data on the volume of Internet trade, as well as the impossibility of predicting both indicators for more than 3-5 years. Considering global trends and trends in the Russian market, we can say that there is a relationship between the indicators.

\section{Conclusion}

Retail trade in offline format will not disappear, but its share will decline, while the share of online retail, on the contrary, will grow, leading to structural changes in retail as a whole: 
- changing the formats of interaction with the buyer (focus on online sales, where you can more effectively analyze the behavior of the buyer, offering him the most advantageous offers);

- a decrease in demand for retail real estate and an increase in demand for warehouse (due to the fact that sales of long-term storage goods through the Internet are growing, the need for large retail space is decreasing, but at the same time, the need for warehouse space is growing);

- expanding the range of goods available for sale online (removal of legal restrictions on the sale of certain goods will increase the volume of online trading and bring new players to the market who will need additional storage space);

- it is possible to change the formats of existing retail space (for example, dividing the total area into zones for direct sale and zones for forming online orders).

Offline trading will always be relevant, but every year its share will decrease due to an increase in the volume of e-commerce.

The article analyzes the dynamics of retail trade: an increase in e-trade, therefore, an increase in its share in the overall structure of retail trade; the impact of the pandemic on retail trade is characterized: the pandemic accelerated the increase in the share of Internet trade in 2020 and adjusted the forecasts for the following periods; the factors influencing structural changes in retail trade are identified.

\section{References}

1. A. Ajupov, A. Sherstobitova, S. Syrotiuk, A. Karataev, International Science Conference SPbWOSCE-2018 "Business Technologies for Sustainable Urban Development” 110, 02040 (2019) DOI 10.1051/e3sconf/201911002040

2. A. Sergeev, L. Akhmetshina, K. Grabovyy, International Science Conference SPbWOSCE-2018 “Business Technologies for Sustainable Urban Development” 110, 02153 (2019) DOI 10.1051/e3sconf/201911002153

3. A. Mecke, I. Lee, J.R. Baker jr., M.M. Banaszak Holl, B.G. Orr, Eur. Phys. J. E 14, 7 (2004)

4. O. Kravchenko, M. Leshchenko, D. Marushchak, Y. Vdovychenko, S. Boguslavska, The 8th International Conference on Monitoring, Modeling \& Management of Emergent Economy 65, 07004, (2019) DOI 10.1051/shsconf/20196507004

5. E. Voskresenskaya, L.Vorona-Slivinskaya, L. Achba, Environmental and Resource Economics 164, 09016, (2020) DOI 10.1051/e3sconf/202016409016

6. O. Pirogova, E. Gorin, V. Plotnikov, The algorithms for the environmental finance based on adjusted present value models, E3S Web of Conferences 91, 08021 (2019)

7. V. Plotnikov, O. Pirogova, Key Competencies as an Enterprise Value Management Tool, IBIMA 2018, 1716-1721 (2018)

8. J. Yoshida, The economic depreciation of real estate: Cross-sectional variations and their return implications, Pacific-Basin Finance Journal 61, 101290 (2020) https://doi.org/10.1016/j.pacfin.2020.101290

9. M. Martín-Peña, J. Sánchez-López, E. Díaz-Garrido, Servitization and digitalization in manufacturing: the influence on firm performance, Journal of Business \& Industrial Marketing 35(3), 564-574 (2018) https://doi.org/10.1108/JBIM-12-2018-0400

10. E. Fang, W.R. Palmatier, J.-B.E. Steenkamp, Effect of Service Transition Strategy on Firm Value, Journal of Marketing 72, 1-14 (2008) https://doi.org/10.1509/jmkg.72.5.1 
11. M.M. Hasan, Corporate life cycle, organizational financial resources and corporate social responsibility, Journal of Contemporary Accounting \& Economics 13, 20-36 (2017) DOI: 10.1016/j.jcae.2017.01.002

12. K.M. Bakarich, M. Hossain, J. Weintrop, Different time, different tone: Company life cycle, Journal of Contemporary Accounting and Economics 15(1), 69-86 (2019) https://doi.org/10.1016/j.jcae.2018.12.002

13. O. Pirogova, V. Plotnikov, Z. Popovic, et al. The Multi-level Model of the Service Enterprises Human Capital Value. (Eds.): TransSiberia 2019, AISC 1116, 738-747 (2020) https://doi.org/10.1007/978-3-030-37919-3_73M.

14. A.A. Salisu, I.D. Raheem, U.B. Ndako, The inflation hedging properties of gold, stocks and real estate: A comparative analysis, Resources Policy 66, 101605 (2020) https://doi.org/10.1016/j.resourpol.2020.101605

15. Ya. Li, D. Zhu, J. Zhao, X. Zheng, L. Zhang, Effect of the housing purchase restriction policy on the Real Estate Market: Evidence from a typical suburb of Beijing, China, Land Use Policy 94, 104528 (2020) https://doi.org/10.1016/j.landusepol.2020.104528

16. V. Skribans, M. Jurušs, M. Demianchuk, N. Maslii, D. Pastory, Real estate announcements monitoring dataset for Latvia 2018, Data in Brief. 28, 105064 (2020) https://doi.org/10.1016/j.dib.2019.105064 